\title{
We need better understanding about functional diversity and vulnerability of tropical freshwater fishes
}

\author{
Jean R. S. Vitule ${ }^{1,2}$ - Angelo A. Agostinho ${ }^{3,4}$ - Valter M. Azevedo-Santos ${ }^{5}$ • \\ Vanessa S. Daga $^{1,6} \cdot$ William R. T. Darwall ${ }^{7} \cdot$ Daniel B. Fitzgerald $^{8}$. \\ Fabrício A. Frehse ${ }^{1,2}$ - David J. Hoeinghaus9 • \\ Dilermando P. Lima-Junior ${ }^{10}$ • André L. B. Magalhães ${ }^{11}$ • \\ Mário L. Orsi ${ }^{12}$ - André A. Padial ${ }^{2,13}$ - Fernando M. Pelicice ${ }^{14}$. \\ Miguel Petrere Jr. ${ }^{15,17}$ - Paulo S. Pompeu ${ }^{16}$ - Kirk O. Winemiller ${ }^{8}$ \\ Received: 6 September 2016/Revised: 4 November 2016/Accepted: 11 November 2016/ \\ Published online: 19 November 2016 \\ (C) The Author(s) 2016. This article is published with open access at Springerlink.com
}

\begin{abstract}
Here we extend a discussion initiated by Toussaint et al. (Sci Rep 6:22125, 2016) concerning the relationship between global patterns of freshwater fish functional diversity (FD) and its vulnerability to human impacts. Based on a set of morphological traits, they concluded that Neotropical freshwater fishes have highest FD, but low vulnerability given high levels of functional redundancy. This conclusion implies that conservation efforts for freshwater fishes should emphasize temperate regions. This
\end{abstract}

Communicated by Angus Jackson.

Jean R. S. Vitule

biovitule@gmail.com

1 Laboratório de Ecologia e Conservação, Departamento de Engenharia Ambiental, Setor de Tecnologia, Universidade Federal do Paraná, Curitiba, Brazil

2 Programa de Pós-Graduação em Ecologia e Conservação, Universidade Federal do Paraná, Curitiba, Brazil

3 Núcleo de Pesquisa em Limnologia, Ictiologia e Aqüicultura (NUPELIA), Universidade Estadual de Maringá, Maringá, Brazil

4 Programa de Pós-Graduação em Ecologia de Ambientes Aquáticos Continentais, Universidade Estadual de Maringá, Maringá, Brazil

5 Laboratório de Ictiologia, Universidade Estadual Paulista, Botucatu, Brazil

6 Programa de Pós-Graduação em Zoologia, Universidade Federal do Paraná, Curitiba, Brazil

7 Global Species Programme, International Union for Conservation of Nature (IUCN), Cambridge, UK

8 Department of Wildlife and Fisheries Sciences, Texas A\&M University, College Station, USA

9 Department of Biological Sciences and Advanced Environmental Research Institute, University of North Texas, Denton, USA

10 Laboratório de Ecologia e Conservação de Ecossistemas Aquáticos, Universidade Federal de Mato Grosso, Pontal do Araguaia, Brazil

11 Programa de Pós-graduação em Tecnologias para o Desenvolvimento Sustentável, Universidade Federal de São João Del Rei, Ouro Branco, Brazil 
perspective is risky, because Toussaint et al.'s study seriously underestimates the full scope of FD, including important ecosystem services provided by fishes in the tropics. We briefly discuss some additional and well-documented aspects of tropical freshwater fish FD and conclude that tropical fish FD is highly vulnerable.

Keywords Conservation policy · Extinction risk · Functional traits · Ecosystem services · Megadiverse regions · Multidimensional niche

Toussaint et al. (2016) offered a thoughtful and much-needed analysis of global patterns in functional diversity (hereafter FD) of freshwater fishes. We applaud their effort to incorporate FD into discussions about the conservation of freshwater biodiversity and for providing a major stimulus for new research. Here we comment on their conclusions and argue for a more comprehensive perspective on FD and, particularly, threats to FD of tropical fishes in megadiverse regions. Toussaint et al. found greatest FD in the Neotropics, the region with highest species richness of freshwater fishes. Their study inferred that functional vulnerability, i.e. potential loss of FD represented by threatened species as assessed by IUCN (2015) and potentially threatened species that occur in a single basin as assessed by Tedesco et al. (2012), is low in the tropics compared to higher latitude regions. They advocate for a greater research and conservation focus on functionally unique species in Palearctic and Nearctic regions, because species in those regions likely contribute disproportionately to ecosystem processes, whereas many vulnerable tropical species are functionally redundant. Few would disagree with their recommendation to broaden the research agenda; however, their analysis clearly underestimated the FD of tropical fishes and its contributions to ecosystem processes and services, as well as the vulnerability of tropical fishes to human impacts. Importantly, their conclusion has potentially harmful implications for conservation given the political challenges in many developing countries in the tropics.

Briefly, we address four main points. First, there is general consensus (e.g. Flynn et al. 2009; Hoeinghaus et al. 2009; Laliberté and Legendre 2010; Cadotte et al. 2011; Vitule et al. 2012; Costa-Pereira and Galetti 2015) that loss of FD can result from a wider range of negative impacts than those considered by Toussaint et al. (2016). Species loss at a regional scale is not required to have significant reduction of FD and impairment of ecosystem processes and services. Population declines lower than the thresholds applied for species assessments for the IUCN Red List of Threatened Species " Brazil

14

Departamento de Biologia Animal e Vegetal, Universidade Estadual de Londrina, Londrina, Brazil

Laboratório de Análise e Síntese em Biodiversidade, Universidade Federal do Paraná, Curitiba,

Núcelo de Estudos Ambientais, Universidade Federal de Tocantins, Porto Nacional, Brazil

Programa de Pós-Graduação em Planejamento e Uso de Recursos Renováveis, Universidade Federal de São Carlos, Sorocaba, Brazil

Laboratório de Ecologia de Peixes, Universidade Federal de Lavras, Lavras, Brazil

Programa de Pós-Graduação em Sustentabilidade de Ecossistemas Costeiros e Marinhos, UNISANTA, Santos, Brazil 
List") can still be sufficient to impair important species interactions and ecosystem processes (e.g. Pendleton et al. 2014; Correa et al. 2015). For example, prochilodontid (e.g. Prochilodus spp.) and loricariid (e.g. Hypostomus spp.) fishes are important ecosystem engineers in the Neotropics. The influence of these species on ecosystem processes, such as nutrient cycling and benthic primary and secondary production, are functions of local population abundance (Flecker and Taylor 2004; Flecker et al. 2010; Mormul et al. 2012; Winemiller et al. 2015). Overexploitation of formerly abundant stocks can change nutrient dynamics (Flecker 1996; Flecker and Taylor 2004; Taylor et al. 2006; Flecker et al. 2010) or riparian forest dynamics (Correa et al. 2015; Costa-Pereira and Galetti 2015). Moreover, rare species can have important contributions to the functional structure of assemblages (Leitão et al. 2016), yet most rare fishes are poorly studied while being highly vulnerable.

Second, current assessments of freshwater fish species extinction risk published on the IUCN Red List are not comprehensive for all regions and therefore do not reflect the full extent of extinction vulnerability of fishes in many regions. Many tropical species, including those that appear in regional Red Lists, have not yet been assessed by IUCN such that the total number of threatened species is likely to be much higher than that currently reported (IUCN 2015; Jaric et al. 2016). This is the case for many Neotropical fishes (e.g. El Salvador-Amatitlania coatepeque, Costa Rica-Piabucina boruca, ColombiaApteronotus magdalenensis, Venezuela_Bryconamericus charalae, Chile-Orestias agassizii, Argentina-Trichomycterus johnsoni, Brazil-Isbrueckerichthys epakmos, Rhamdiopsis moreirai, Spintherobolus ankoseion, Steindachneridion parahybae and Steindachneridion doceana). In many tropical regions, local stocks currently fail to support viable fisheries (Allan et al. 2005; Hoeinghaus et al. 2009; Vieira and Rodrigues 2010). Similarly, several large migratory fishes (e.g. Pseudoplatystoma spp., Salminus spp.) have been eliminated from major segments of Neotropical rivers, yet they are not included on regional red lists because they persist in other segments, including some where they were stocked (e.g. Clavero and García-Berthou 2005; Vitule et al. 2014). Currently, levels of threat to the FD of megadiverse tropical fishes is poorly documented and clearly underestimated.

Third, the ecomorphological paradigm assumes that clusters of specimens or species within morphological spaces represent functional groups (Thuiller et al. 2010; Azzurro et al. 2014). Although some aspects of fish morphology provide reasonable surrogates for components of ecological performance, and Toussaint et al.'s (2016) finding for highest FD in the tropics is consistent with prior research (e.g. Winemiller 1991), important life history, physiological and behavioral dimensions of the niche are missing from analysis based solely on body shape measurements (Winemiller et al. 2015). For example, some tropical fish species are morphologically similar but differ in their physiology, ecology and spatial distributions (e.g. Lobón-Cerviá and Bennemann 2000; Nunes et al. 2014; Duponchelle et al. 2016). In addition, fishes have indeterminate growth influenced by environmental variation and populations with broad size distribution diversity; therefore, FD should have significant intraspecific and seasonal variations (e.g. Blanck and Lamouroux 2007). Analysis of more kinds of traits and intraspecific variation would enhance estimates of FD for conservation applications (Skóra et al. 2015).

Finally, future threats to biodiversity are greater in the tropics compared with temperate regions where species diversity tends to be much lower, the most severe human impacts have already happened, and restoration is a serious undertaking. The tropics experienced profound changes during the twentieth century that impacted freshwater ecosystems and fishes (e.g. Dudgeon et al. 2006; Bovarnick et al. 2010; Vitule et al. 2012; Araújo et al. 2013; Castello et al. 2013; Lees et al. 2016). Given the demographic and economic 
realities, impacts to tropical freshwater ecosystems (e.g. overfishing, dams, watershed deforestation, pollution, biological invasions) will only increase (Allan et al. 2005; Casatti 2010; Pelicice et al. 2014; Azevedo-Santos et al. 2015, 2016; Vitule et al. 2015; Agostinho et al. 2016 ). In Brazil, efforts to restore impacted native fish stocks have been largely ineffective (Pelicice et al. 2015) and this failure likely is associated with the FD of tropical fishes, such that a single solution may not be effective for all species. The high FD of megadiverse tropical fish assemblages does not mitigate the need for conservation; instead, it increases our conservation challenges.

In our opinion, Toussaint et al.'s finding of low FD vulnerability of tropical fishes misinforms conservation. The current biodiversity crisis is particularly serious in megadiverse tropical regions (Frehse et al. 2016). The suggestion that threatened freshwater fishes in the tropics might merit less attention compared to temperate fishes misleads policymakers in developing countries, some of which are facing serious political, social and economic challenges that hinder conservation initiatives.

Acknowledgements The authors are grateful to the anonymous reviewers for their constructive comments on previous versions of this manuscript. We are also especially thankful to CNPq (Conselho Nacional de Desenvolvimento Científico e Tecnológico) and CAPES (Coordenação de Aperfeiçoamento de Pessoal de Nivel Superior) for scholarships and constant financial support.

Open Access This article is distributed under the terms of the Creative Commons Attribution 4.0 International License (http://creativecommons.org/licenses/by/4.0/), which permits unrestricted use, distribution, and reproduction in any medium, provided you give appropriate credit to the original author(s) and the source, provide a link to the Creative Commons license, and indicate if changes were made.

\section{References}

Agostinho AA, Gomes LC, Santos NCL, Ortega JCG, Pelicice FM (2016) Fish assemblages in Neotropical reservoirs: colonization patterns, impacts and management. Fish Res 173:26-36. doi:10.1016/j.fishres. 2015.04.006

Allan JD, Abell R, Hogan Z, Revenga C, Taylor B, Welcomme R, Winemiller KO (2005) Overfishing of inland waters. BioScience 55:1041-1051

Araújo ES, Marques EE, Freitas IS, Neuberger AL, Fernandes R, Pelicice FM (2013) Changes in distance decay relationships after river regulation: similarity among fish assemblages in a large Amazonian river. Ecol Freshw Fish 22:543-552. doi:10.1111/eff.12054

Azevedo-Santos VM, Pelicice FM, Lima-Junior DP, Magalhães ALB, Orsi ML, Vitule JRS, Agostinho AA (2015) How to avoid fish introductions in Brazil: education and information as alternatives. Nat Conserv 13:123-132. doi:10.1016/j.ncon.2015.06.002

Azevedo-Santos VM, Garcia-Ayala JR, Fearnside PM, Esteves FA, Pelicice FM, Laurance WF, Benine RC (2016) Amazon aquatic biodiversity imperiled by oil spills. Biodivers Conserv 25:2831-2834. doi:10. 1007/s10531-016-1192-9

Azzurro E, Tuset VM, Lombarte A, Maynou F, Simberloff D, Rodríguez-Pérez A, Solé RV (2014) External morphology explains the success of biological invasions. Ecol Lett 17:1455-1463. doi:10.1111/ele. 12351

Blanck A, Lamouroux N (2007) Large-scale intraspecific variation in life-history traits of European freshwater fish. J Biogeogr 34:862-875. doi:10.1111/j.1365-2699.2006.01654.x

Bovarnick A, Alpizar F, Schnell C (2010) The importance of biodiversity and ecosystems in economic growth and equity in Latin America and the Caribbean: an economic valuation of ecosystems. United Nations Development Programme, New York

Cadotte MW, Carscadden K, Mirotchnick N (2011) Beyond species: functional diversity and the maintenance of ecological processes and services. J Appl Ecol 48:1079-1087. doi:10.1111/j.1365-2664.2011. 02048.x

Casatti L (2010) Alterações no Código Florestal Brasileiro: impactos potenciais sobre a ictiofauna. Biota Neotrop 10:31-34. doi:10.1590/S1676-06032010000400002 
Castello L, McGrath DG, Hess LL, Coe MT, Lefebvre PA, Petry P, Macedo MN, Renó VF, Arantes CC (2013) The vulnerability of Amazon freshwater ecosystems. Conserv Lett 6:217-229. doi:10.1111/ conl.12008

Clavero M, García-Berthou E (2005) Invasive species are a leading cause of animal extinctions. Trends Ecol Evol 20:110. doi:10.1016/j.tree.2005.01.003

Correa SB, Araujo JK, Penha JMF, Cunha CN, Stevenson PR, Anderson JT (2015) Overfishing disrupts an ancient mutualism between frugivorous fishes and plants in Neotropical wetlands. Biol Conserv 191:159-167. doi:10.1016/j.biocon.2015.06.019

Costa-Pereira R, Galetti M (2015) Frugivore downsizing and the collapse of seed dispersal by fish. Biol Conserv 191:809-811. doi:10.1016/j.biocon.2015.07.011

Dudgeon D, Arthington AH, Gessner MO, Kawabata Z, Knowler DJ, Lévêque C, Naiman RJ, PrieurRichard AH, Soto D, Stiassny MLJ, Sullivan CA (2006) Freshwater biodiversity: importance, threats, status and conservation challenges. Biol Rev 81:163-182. doi:10.1017/S1464793105006950

Duponchelle F, Pouilly M, Pécheyran C, Hauser M, Renno JF, Panfili J, Darnaude AM, García-Vasquez A, Carvajal-Vallejos F, García-Dávila C, Doria C, Bérail S, Donard A, Sondag F, Snatos RV, Nuñez J, Point D, Labonne M, Baras E (2016) Trans-Amazonian natal homing in giant catfish. J Appl Ecol. doi:10.1111/1365-2664.12665

Flecker AS (1996) Ecosystem engineering by a dominant detritivore in a diverse tropical stream. Ecology 77:1845-1854. doi:10.2307/2265788

Flecker AS, Taylor BW (2004) Tropical fishes as biological bulldozers: density effects on resource heterogeneity and species diversity. Ecology 85:2267-2278

Flecker AS, McIntyre PB, Moore JW, Anderson JT, Taylor BW, Hall RO Jr. (2010) Migratory fishes as material and process subsidies in riverine ecosystems. Am Fish Soc Symp 73:559-592

Flynn DFB, Gogol-Prokurat M, Nogeire T, Molinari N, Richers BT, Lin BB, Simpson N, Mayfield MM, DeClerck F (2009) Loss of functional diversity under land use intensification across multiple taxa. Ecol Lett 12:22-33. doi:10.1111/j.1461-0248.2008.01255.x

Frehse FA, Braga RR, Nocera GA, Vitule JRS (2016) Non-native species and invasion biology in a megadiverse country: scientometric analysis and ecological interactions in Brazil. Biol Invasions. doi:10.1007/s10530-016-1260-9

Hoeinghaus DJ, Agostinho AA, Gomes LC, Pelicice FM, Okada EK, Latini JD, Kashiwaqui EAL, Winemiller KO (2009) Effects of river impoundment on ecosystem services of large tropical rivers: embodied energy and market value of artisanal fisheries. Conserv Biol 23:1222-1231. doi:10.1111/j. 1523-1739.2009.01248.x

IUCN (2015) The IUCN Red List of Threatened Species. Version 2015-4. http://www.iucnredlist.org. Accessed 19 Nov 2015

Jarić I, Courchamp F, Gessner J, Roberts DL (2016) Potentially threatened: a Data Deficient flag for conservation management. Biodivers Conserv 25:1995-2000. doi:10.1007/s10531-016-1164-0

Laliberté E, Legendre P (2010) A distance-based framework for measuring functional diversity from multiple traits. Ecology 91:299-305. doi:10.1890/08-2244.1

Lees AC, Peres CA, Fearnside PM, Schneider M, Zuanon JAS (2016) Hydropower and the future of Amazonian biodiversity. Biodivers Conserv 25:451-466. doi:10.1007/s10531-016-1072-3

Leitão RP, Zuanon J, Villéger S, Williams SE, Baraloto C, Fortunel C, Mendonça FP, Mouillot D (2016) Rare species contribute disproportionately to the functional structure of species assemblages. Proc R Soc B 283:20160084. doi:10.1098/rspb.2016.0084

Lobón-Cerviá J, Bennemann ST (2000) Temporal trophic shifts and feeding in two sympatric, neotropical, omnivorous fishes: Astyanax bimaculatus and Pimelodus maculatus in Rio Tibagi (Paraná, Southern Brazil). Arch Hydrobiol 149:285-306. doi:10.1127/archiv-hydrobiol/149/2000/285

Mormul RP, Thomaz SM, Agostinho AA, Bonecker CC, Mazzeo N (2012) Migratory benthic fishes may induce regime shifts in a tropical floodplain pond. Freshw Biol 57:1592-1602. doi:10.1111/j.13652427.2012.02820.x

Nunes MV, Rocha O, Verani JR (2014) Trophic interactions between the fish Geophagus brasiliensis (Cichlidae) and the benthic macroinvertebrate community. Stud Neotrop Fauna Environ 49:11-17. doi:10.1080/01650521.2014.904551

Pelicice FM, Vitule JRS, Lima-Junior DP, Orsi ML, Agostinho AA (2014) Serious new threat to Brazilian freshwater ecosystems: the naturalization of nonnative fish by decree. Conserv Lett 7:55-60. doi:10. $1111 /$ conl.12029

Pelicice FM, Pompeu PS, Agostinho AA (2015) Large reservoirs as ecological barriers to downstream movements of Neotropical migratory fish. Fish Fish 16:697-715. doi:10.1111/faf.12089 
Pendleton RM, Hoeinghaus DJ, Gomes LC, Agostinho AA (2014) Loss of rare fish species from tropical floodplain food webs affects community structure and ecosystem multifunctionality in a mesocosm experiment. PLoS ONE 9(1):e84568. doi:10.1371/journal.pone.0084568

Skóra F, Abilhoa V, Padial AA, Vitule JRS (2015) Darwin's hypotheses to explain colonization trends: evidence from a quasi-natural experiment and a new conceptual model. Divers Distrib 21:583-594. doi: $10.1111 /$ ddi. 12308

Taylor BW, Flecker AS, Hall RO Jr (2006) Loss of a harvested fish species disrupts carbon flow in a diverse tropical river. Science 313:833-836. doi:10.1126/science.1128223

Tedesco PA, Leprieur F, Hugueny B, Brosse S, Dürr HH, Beauchard O, Busson F, Oberdorff T (2012) Patterns and processes of global riverine fish endemism. Glob Ecol Biogeogr 21:977-987. doi:10.1111/ j.1466-8238.2011.00749.x

Thuiller W, Gallien L, Boulamgeat I, Bello F, Münkemüller T, Roquet C, Lavergne S (2010) Resolving Darwin's naturalization conundrum: a quest for evidence. Divers Distrib 16:461-475. doi:10.1111/j. 1472-4642.2010.00645.x

Toussaint A, Charpin N, Brosse S, Villéger S (2016) Global functional diversity of freshwater fish is concentrated in the Neotropics while functional vulnerability is widespread. Sci Rep 6:22125. doi:10. $1038 /$ srep 22125

Vieira F, Rodrigues RR (2010) A fauna de peixes dos afluentes do rio Paraíba do Sul no estado de Minas Gerais. MG Biota 3:5-23. https://www.cemig.com.br/pt-br/A_Cemig_e_o_Futuro/sustentabilidade/ nossos_programas/ambientais/peixe_vivo/publicacoes/Documents/MG_Biota\%203a\%20Edi\%C3\% A7\%C3\%A3o.pdf

Vitule JRS, Skóra F, Abilhoa V (2012) Homogenization of freshwater fish faunas after the elimination of a natural barrier by a dam in Neotropics. Divers Distrib 18:111-120. doi:10.1111/j.1472-4642.2011. 00821.x

Vitule JRS, Bornatowski H, Freire CA, Abilhoa V (2014) Extralimital introductions of Salminus brasiliensis (Cuvier, 1816) (Teleostei, Characidae) for sport fishing purposes: a growing challenge for the conservation of biodiversity in neotropical aquatic ecosystems. BioInvasions Rec 3(4):291-296. doi:10. 3391/bir.2014.3.4.11

Vitule JRS, Azevedo-Santos VM, Daga VS, Lima-Junior DP, Magalhães ALB, Orsi ML, Pelicice FM, Agostinho AA (2015) Brazil's drought: protect biodiversity. Science 347:1427-1428. doi:10.1126/ science.347.6229.1427-b

Winemiller KO (1991) Ecomorphological diversification of freshwater fish assemblages from five biotic regions. Ecol Monogr 61:343-365. doi:10.2307/2937046

Winemiller KO, Fitzgerald DB, Bower LM, Pianka ER (2015) Functional traits, convergent evolution, and periodic tables of niches. Ecol Lett 18:737-751. doi:10.1111/ele.12462 